\title{
Primary hypothyroidism and the low T3 syndrome in thalassaemia major
}

\author{
A R SABATO, V DE SANCTIS, G ATTI, L CAPRA, B BAGNi, AND C VUllo \\ Thalassaemia Centre of the Department of Paediatrics, and Department of Biophysics, Arcispedale S Anna, \\ Ferrara, Italy
}

SUMMARY Basal thyroid function was assessed from the serum thyroxine, triiodothyronine, and thyroid-stimulating hormone concentrations in 114 patients (mean age $13 \cdot 6$ years), designated group 1 , with thalassaemia major. Forty of these patients were further evaluated (group 2) for serum-free thyroxine, and free and reverse triiodothyronine concentrations. The response of thyroid-stimulating hormone to thyrotrophin-releasing hormone was measured in 25 patients from this subgroup. Results were compared with those from 53 control subjects. Primary hypothyroidism, defined by a raised thyroid-stimulating hormone level above the upper range limit of $6.5 \mu \mathrm{IU} / \mathrm{ml}$ of the controls, was present in $17.5 \%$ of the 114 patients. In group 2 patients, a spectrum of thyroid disease spanning uncompensated and compensated primary hypothyroidism and decreased thyroid reserve was evident. The presence of primary hypothyroidism (uncompensated and compensated) was associated with an age of at least 10 years, an increased incidence of iron toxicity-related systemic complications, and an increased transfusion iron load, but not with an increased serum ferritin level. In the total 114 patients there were 9 who had the low triiodothyronine (sick euthyroid) syndrome. Primary hypothyroidism occurs in a significant proportion of thalassaemia major patients in the absence of obvious clinical signs of hypothyroidism; the low triiodothyronine syndrome associated with non-thyroidal disease is not uncommon.

Transfusion-related iron overload is the primary therapeutic complication in thalassaemia major. Haemosiderosis of various endocrine glands including the thyroid gland has been documented histologically, ${ }^{1}$ and clinical evidence of decreased endocrine function, particular failure of pubertal development, is often found after the first decade of life. ${ }^{2}$

Dysfunction usually occurs at the peripheral endocrine glands. ${ }^{3}$ Pubertal failure is generally associated with decreased pituitary gonadotrophin secretion, ${ }^{4}$ but gonadal endocrine failure has also

$$
\begin{aligned}
& \text { T3 = triiodothyronine } \\
& \text { T4 = thyroxine } \\
& \text { TSH = thyroid stimulating hormone } \\
& \text { FT4 = serum-free thyroxine } \\
& \text { FT3 = serum-free triiodothyronine } \\
& \text { rT3 = reverse triiodothyronine } \\
& \text { TRH = thyrotrophin-releasing hormone } \\
& \text { TBG = thyroxin-binding globulin }
\end{aligned}
$$

been reported. ${ }^{56}$ Multiple endocrine disturbances may occur.?

Thyroid gland function in thalassaemia major has been reported as ranging from normal, ${ }^{8-10}$ to decreased reserve, ${ }^{3511}$ to primary hypothyroidism. ${ }^{1213}$ The low T3 syndrome has not been reported in association with thalassaemia major.

The aim of this study was to determine the incidence of hypothyroidism, its severity, and relationship to various clinical measurements in thalassaemic patients.

\section{Subjects and methods}

The 114 randomly selected transfusion-dependent patients had homozygous $\beta$-thalassaemia diagnosed on clinical, haematological, and genetic criteria. Their mean age was $13.6 \pm 4.9$ years $( \pm 1$ SD) with a range of $3 \cdot 2$ to $30 \cdot 8$ years. Blood transfusions were started before age 2 years in $73 \%$ and, with the exception of one patient, by 7 years in the others. Standard treatment ${ }^{2}$ was regularly administered to $70 \%$ of this group at one centre in Ferrara, Italy. Haemoglobin levels have been maintained above 
8-9 g/dl. Desferrioxamine therapy by regular intramuscular injection has been in use since 1973 and for the last 4 years by subcutaneous infusion. All patients were prescribed daily vitamin $\mathrm{C}$ and folic acid. Penicillin prophylaxis for splenectomised patients, prednisolone for 5 patients with chronic active hepatitis, and insulin for 4 children with diabetes mellitus were the only other drugs prescribed. The remaining $30 \%$ of the patients were treated near their homes and seen infrequently at the centre.

Of the $73 \%$ of patients who originated from the Po delta, $65 \%$ were from Ferrara $\left(\beta^{\circ}\right.$ thalassaemia in $90 \%$ ) and the remaining $35 \%$ came from nearby towns $\left(\beta^{+}\right.$thalassaemia in $70 \%$ ) (F Conconi, personal communication). The $27 \%$ of non-Po delta patients were from southern Italy, Sardinia, or Sicily.

Blood samples were taken from patients on the morning of attendance for regular blood transfusion and at least 2 weeks after the previous transfusion. Patients with acute illness ${ }^{14}$ or with a family history of thyroid disease were excluded. Commercial radioimmunoassay technique was used to determine the serum concentration of T4, T3, and TSH (Diagnostic Product Corporation) in the 114 (group 1) patients. Forty patients were chosen from this group because of adequately documented clinical and investigational data for more definitive thyroid function studies. These $\mathbf{4 0}$ patients (group 2) had radioimmunoassay of FT4 and FT3 (DowLepitit Laboratory), rT3 (the laboratory method has been described elsewhere), ${ }^{15}$ and TBG (Sorin Biomedica).

Twenty-five patients from group 2 consented to have a TRH test performed. A basal state blood sample for TSH concentration was taken from an intravenous line inserted 30 minutes previously and kept patent by saline infusion. A standard dose $(200 \mu \mathrm{g})$ of synthetic TRH was then injected intravenously and further samples were taken at 20,40 , and 60 minutes. The serum was separated and frozen at $-20^{\circ} \mathrm{C}$ until assayed for TSH concentration. Serum antithyroglobulin in antibody titre (commercial radioimmunoassay-Sorin Biomedica) was also determined in these 25 patients.

The thyroid function status of the group 2 patients was defined as compensated (increased TSH and normal FT4) and uncompensated (increased TSH and decreased FT4) primary hypothyroidism, and euthyroidism (normal TSH and FT4). Decreased thyroid gland reserve was inferred from an increased TSH response from normal basal levels after TRH stimulation.

Height and weight were measured at each attendance for blood transfusion. The height age was determined from the charts of Tanner and
Whitehouse. Skeletal maturation was determined from the TW2-20 bone score. ${ }^{16}$ The transfusion iron load was derived from the product of the total number of units of packed cells (equivalent to $300 \mathrm{ml}$ of whole blood) and $133 \mathrm{mg}$ of iron in each unit. Serum ferritin concentration was determined by a commercial radioimmunoassay kit (Ramco Laboratories).

A control group of 53 normal subjects had samples taken for T4, T3, and TSH and 20 samples were randomly selected from this group for FT4, FT3, rT3, and TBG estimation. A TRH test was performed on 17 of the 53 subjects. The age of the control subjects ranged from $3 \cdot 3$ to 35 years with a mean of $13.4( \pm 7.7)$ years $( \pm 1 \mathrm{SD})$. The control group comprised normal subjects attending the hospital for genetic screening, children investigated for short stature, subsequently diagnosed as constitutional, and staff from the laboratory.

A TSH concentration above the upper range of the control subjects was accepted as increased (control TSH: range $0 \cdot 5-6.5 \mu \mathrm{IU} / \mathrm{ml}$; mean $( \pm 1$ SD) $=3.01( \pm 1 \cdot 33) \mu \mathrm{IU} / \mathrm{ml})$. An FT4 concentration less than 2 standard deviations from the mean for the control subjects was defined as decreased (control mean FT4 $( \pm 2$ SD) $=12.4( \pm 4.8)$ $\mathrm{pg} / \mathrm{ml}(16 \cdot 0 \pm 6 \cdot 2 \mathrm{pmol} / \mathrm{l}))$.

Informed consent was obtained from all patients and subjects or their parents.

Statistical analysis was performed using Wilcoxon's nonparametric test if $n \leqslant 30$ and the Student's $t$ test if $\mathrm{n}>30$.

\section{Results}

Primary hypothyroidism was present in $17.5 \%$ of the 114 patients. A TSH level greater than 10 $\mu \mathrm{IU} / \mathrm{ml}$ was present in $8 \%$ and in 3 patients it was at least $45 \mu \mathrm{IU} / \mathrm{ml}$. All patients were clinically euthyroid, but some symptoms (for example lethargy and growth failure) may not have been identified as separate from those of the primary disease. None had a goitre. There was no difference in the incidence of hypothyroidism between boys and girls. An age-dependent decrease in T4, T3, and TSH concentration was not apparent in the control subjects, as was reported to occur in a series of a larger number of normal subjects, ${ }^{17}$ nor was it present in group 1 patients. Therefore the children were divided into groups according to age, and compared with the control group (Fig. 1). The T4 and T3 levels were significantly decreased and the TSH level significantly increased in the groups of older thalassaemic patients compared with the controls (Fig. 1). The mean T3 concentration decreased progressively with increase in age. The TSH concentration increased up to the 11-15 year age group with a decrease, but 


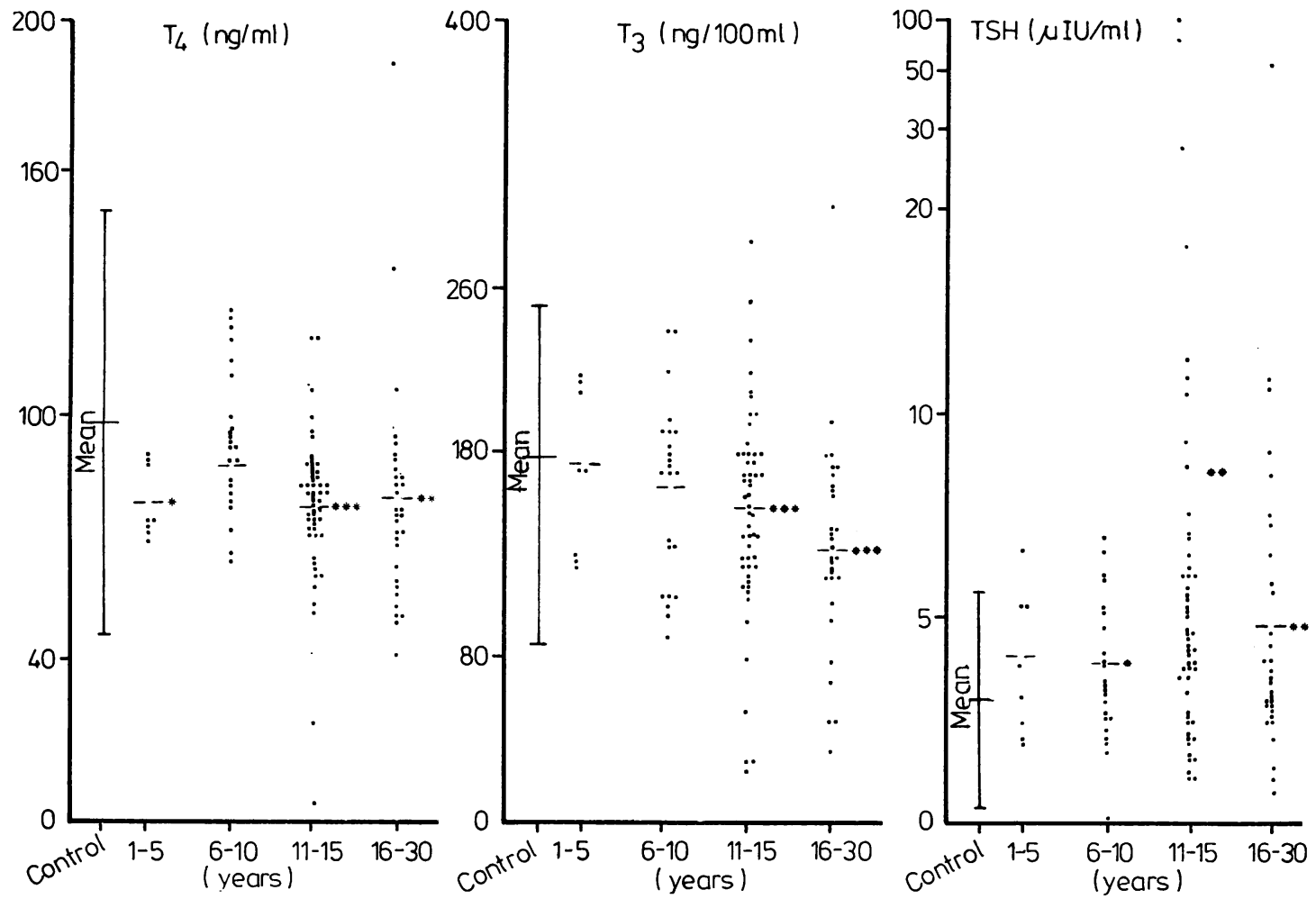

Fig. 1 Serum T4, T3, and TSH concentration in 114 patients with thalassaemia major classified by age group and compared with mean $\pm 2 S D$ s of 53 control subjects. ${ }^{*} P<0.05,{ }^{* *} P<0.01,{ }^{* * *} P<0.001$.

still significantly above the mean of the controls, in the 16-30 year age group (Fig. 1).

The proportion of patients with primary hypothyroidism (TSH level greater than $6.5 \mu \mathrm{IU} / \mathrm{ml}$ ) was similar for children who came from outside the Po delta $(16.1 \%)$ as for those native to the region $(18.1 \%)$. Of the patients from the Po delta, hypothyroidism was disproportionately low in the Ferrara $\beta^{\circ}$ thalassaemic patients $(11.1 \%)$ compared with the predominantly $\beta^{+}$non-Ferrara Po delta patients $(31.0 \%)$.

Nine patients (mean age 17.5; range 10.5-24.5 years) had a pattern of hormone levels characteristic of the low T3 syndrome. All had normal TSH and T4 concentrations, but T3 levels were low. FT3 concentrations, measured in 2 patients, were also low. The TSH response to TRH stimulation was normal in all 5 patients tested. Two patients had chronic liver disease confirmed by biopsies.

Uncompensated and compensated primary hypothyroidism was found in 8 and 5 patients respectively from the 40 group 2 patients (Table 1). The remaining
27 patients were euthyroid. Thalassaemic patients defined as euthyroid had mean T4, T3, and FT3 concentrations comparable with the respective means of the control subjects. However, the mean rT3 concentration was decreased and the mean TBG concentration was increased compared with the controls (Table 2). Decreased thyroid function was associated with an increased total transfusion iron load, an increased overall rate of iron load, and an increased iron load per kilogram body weight. It did not relate to the ferritin levels (Table 3 ). The transfusion iron load in the hypothyroid patients ranged from 0.7 to $1.4 \mathrm{~g} / \mathrm{kg}$ of body weight. Iron toxicity-related complications-such as insulindependent diabetes, delayed pubertal development, cardiac failure, and death-occurred proportionately more often in the hypothyroid patients (Table 4).

Conversely, evidence for a milder form of thalassaemia was present in the euthyroid patients with 11 of the 27 starting transfusions after age 2 years, compared with 1 of the 13 hypothyroid patients. Similarly splenectomy had been performed 
Table 1 Results of thyroid function of the group 2 thalassaemic patients with uncompensated (Cases 1-8) and compensated (Cases 9-13) hypothyroidism

\begin{tabular}{|c|c|c|c|c|c|c|c|}
\hline Cases & $\begin{array}{l}T 4(\mathrm{ng} / \mathrm{ml}) \\
96 \cdot 3 \pm 26 \cdot 0^{*}\end{array}$ & $\begin{array}{l}F T 4(\mathrm{pg} / \mathrm{ml}) \\
12 \cdot 4 \pm 1 \cdot 9^{*}\end{array}$ & $\begin{array}{l}T 3(\mathrm{ng} / 100 \mathrm{ml}) \\
164 \cdot 2 \pm 46 \cdot 6^{*}\end{array}$ & $\begin{array}{l}F T 3(\mathrm{pg} / \mathrm{ml}) \\
5 \cdot 1 \pm 1 \cdot 3^{*}\end{array}$ & $\begin{array}{l}T S H(\mu I U / m l) \\
3 \cdot 01 \pm 1 \cdot 33^{*}\end{array}$ & $\begin{array}{l}r T 3(\mathrm{ng} / 100 \mathrm{ml}) \\
29 \cdot 5 \pm 5 \cdot 7^{*}\end{array}$ & $\begin{array}{l}T B G(\mu \mathrm{g} / \mathrm{ml}) \\
19 \cdot 2 \pm 4 \cdot 7^{*}\end{array}$ \\
\hline $\begin{array}{r}1 \\
2 \\
3 \\
4 \\
5 \\
6 \\
7 \\
7 \\
8 \\
9 \\
10 \\
11 \\
12 \\
13\end{array}$ & $\begin{array}{r}52 \\
57 \\
87 \\
87 \\
52 \\
24 \\
58 \\
73 \\
79 \\
82 \\
82 \\
135 \\
80\end{array}$ & $\begin{array}{l}0 \cdot 5 \\
6 \cdot 2 \\
6 \cdot 4 \\
6 \cdot 9 \\
7 \cdot 3 \\
5 \cdot 0 \\
7 \cdot 1 \\
7 \cdot 3 \\
8 \cdot 7 \\
7 \cdot 6 \\
9 \cdot 8 \\
8 \cdot 7 \\
9 \cdot 2\end{array}$ & $\begin{array}{r}125 \\
115 \\
167 \\
236 \\
113 \\
25 \\
120 \\
141 \\
141 \\
159 \\
180 \\
196 \\
128\end{array}$ & $\begin{array}{l}0 \cdot 5 \\
2 \cdot 8 \\
4 \cdot 9 \\
4 \cdot 0 \\
4 \cdot 4 \\
2 \cdot 8 \\
5 \cdot 2 \\
4 \cdot 4 \\
3 \cdot 7 \\
4 \cdot 9 \\
5 \cdot 9 \\
5 \cdot 2 \\
3 \cdot 5\end{array}$ & $\begin{array}{r}>100 \\
18 \cdot 0 \\
12 \cdot 5 \\
7.0 \\
45 \cdot 0 \\
>80 \\
11 \cdot 6 \\
7.2 \\
7.5 \\
8.6 \\
9.2 \\
8.4 \\
11 \cdot 0\end{array}$ & \begin{tabular}{r}
\multicolumn{1}{c}{0} \\
$15 \cdot 0$ \\
$13 \cdot 7$ \\
$11 \cdot 0$ \\
$4 \cdot 1$ \\
$4 \cdot 9$ \\
$7 \cdot 9$ \\
$7 \cdot 7$ \\
$13 \cdot 1$ \\
$6 \cdot 9$ \\
$5 \cdot 9$ \\
$16 \cdot 2$ \\
$4 \cdot 9$
\end{tabular} & $\begin{array}{l}28 \cdot 0 \\
16 \cdot 0 \\
55 \cdot 7 \\
26 \cdot 0 \\
54 \cdot 2 \\
27 \cdot 0 \\
29 \cdot 6 \\
49 \cdot 9 \\
24 \cdot 0 \\
21 \cdot 9 \\
21 \cdot 3 \\
38 \cdot 9 \\
23 \cdot 0\end{array}$ \\
\hline
\end{tabular}

*Values for controls (mean \pm SD).

Table 2 Serum thyroid hormones (total and free), rT3, TBG, and TSH concentrations in group 2 thalassaemic patients with uncompensated hypothyroid function, compared with those in euthyroid patients and control subjects

\begin{tabular}{|c|c|c|c|c|c|c|c|c|}
\hline & & $T 4(n g / m l)$ & $T 3(n g / 100 m l)$ & $F T 4(p g / m l)$ & $F T 3(p g / m l)$ & $r T 3(n g / 100 m l)$ & $T B G(\mu g / m l)$ & $T S H(\mu I U / m l)$ \\
\hline $\begin{array}{l}\text { (A) Euthyroid patients } \\
\text { (B) Uncompensated } \\
\text { hypothyroid patients } \\
\text { (C) Control subjects }\end{array}$ & $\begin{array}{l}\mathbf{n} \\
\mathbf{n} \\
\mathbf{n}\end{array}$ & $\begin{array}{l}88 \cdot 7 \pm 22 \cdot 9 \\
(27) \\
61 \cdot 2 \pm 20 \cdot 9 \\
(8) \\
96 \cdot 3 \pm 26 \cdot 0 \\
(53)\end{array}$ & $\begin{array}{l}159 \cdot 7 \pm 44 \cdot 2 \\
(27) \\
130 \cdot 2 \pm 59 \cdot 0 \\
(8) \\
177 \cdot 1 \pm 37 \cdot 3 \\
(53)\end{array}$ & $\begin{array}{l}8 \cdot 8 \pm 1 \cdot 7 \\
(27) \\
5 \cdot 8 \pm 2 \cdot 3 \\
(8) \\
12 \cdot 4 \pm 1 \cdot 9 \\
(20)\end{array}$ & $\begin{array}{l}5 \cdot 2 \pm 1 \cdot 3 \\
(27) \\
3 \cdot 6 \pm 1 \cdot 5 \\
(8) \\
5 \cdot 6 \pm 0 \cdot 8 \\
(20)\end{array}$ & $\begin{array}{l}12 \cdot 1 \pm 9 \cdot 1 \\
(27) \\
8 \cdot 0 \pm 5 \cdot 1 \\
(8) \\
29 \cdot 5 \pm 5 \cdot 7 \\
(20)\end{array}$ & $\begin{array}{l}28 \cdot 6 \pm 11 \cdot 5 \\
(27) \\
35 \cdot 8 \pm 15 \cdot 1 \\
(8) \\
19 \cdot 2 \pm 4 \cdot 7 \\
(20)\end{array}$ & $\begin{array}{l}2 \cdot 89 \pm 1 \cdot 6 \\
(27) \\
35 \cdot 2 \pm 36 \cdot 4 \\
(8) \\
3 \cdot 01 \pm 1 \cdot 33 \\
(53)\end{array}$ \\
\hline $\begin{array}{l}\text { A compared with } \mathbf{B} \\
\text { A compared with } \mathbf{C}\end{array}$ & $\begin{array}{l}\mathbf{P} \\
\mathbf{P}\end{array}$ & $\begin{array}{l}<0.01 \\
\text { NS }\end{array}$ & $\begin{array}{l}<0.05 \\
\text { NS }\end{array}$ & - & $\begin{array}{l}<0.001 \\
\text { NS }\end{array}$ & $\begin{array}{l}\text { NS } \\
<0.001\end{array}$ & $\begin{array}{l}\text { NS } \\
<0.001\end{array}$ & - \\
\hline
\end{tabular}

Conversion: traditional to SI units-T4 $1 \mathrm{ng} / \mathrm{ml} \approx 1 \cdot 287 \mathrm{nmol} / 1 ; \mathrm{T} 31 \mathrm{ng} / 100 \mathrm{ml} \approx 15 \cdot 4 \mathrm{pmol} / 1 ; \mathrm{rT} 31 \mathrm{ng} / 100 \mathrm{ml} \approx 15 \cdot 4 \mathrm{pmol} / 1 ; \mathrm{FT} 41 \mathrm{pg} / \mathrm{ml} \approx 1 \cdot 287$ $\mathrm{pmol} / 1 ;$ FT $31 \mathrm{pg} / \mathrm{ml} \approx 1 \cdot 54 \mathrm{pmol} / 1$.

Hypothyroid function-TSH $>6.5 \mu \mathrm{IU} / \mathrm{ml}$ and FT $4<7.6 \mathrm{pg} / \mathrm{ml}$, euthyroid function-TSH $\leq 6 \cdot 5 \mu \mathrm{IU} / \mathrm{ml}$.

Table 3 Data (mean $\pm 1 S D)$ for the hypothyroid (compensated and uncompensated) and euthyroid patients in group 2

\begin{tabular}{|c|c|c|c|c|c|c|c|c|}
\hline & & $\begin{array}{l}\text { Chronological } \\
\text { age (years) }\end{array}$ & $\begin{array}{l}\text { Height age } \\
\text { (years) }\end{array}$ & $\begin{array}{l}\text { Total units blood } \\
\text { transfused }\end{array}$ & Units/kg & Units/year & $\begin{array}{l}\text { Ferritin } \times 10^{3} \\
(\mathrm{ng} / \mathrm{ml})\end{array}$ & $\begin{array}{l}\text { Albumin } \\
(g / l)\end{array}$ \\
\hline $\begin{array}{l}\text { Euthyroid } \\
\text { Hypothyroid }\end{array}$ & $\begin{array}{l}\mathbf{n} \\
\mathbf{n} \\
\mathbf{P}\end{array}$ & $\begin{array}{l}13 \cdot 8 \pm 6 \cdot 3 \\
(27) \\
15 \cdot 4 \pm 3 \cdot 4 \\
(13) \\
\text { NS }\end{array}$ & $\begin{array}{l}11 \cdot 3 \pm 3 \cdot 6 \\
(27) \\
11 \cdot 5 \pm 1 \cdot 2 \\
(13) \\
\text { NS }\end{array}$ & $\begin{array}{l}218 \cdot 5 \pm 116 \cdot 2 \\
(24) \\
298 \cdot 5 \pm 64 \cdot 5 \\
(11) \\
<0.05\end{array}$ & $\begin{array}{l}5 \cdot 96 \pm 1 \cdot 91 \\
(24) \\
8 \cdot 10 \pm 1 \cdot 80 \\
(11) \\
<0.05\end{array}$ & $\begin{array}{l}15 \cdot 2 \pm 4 \cdot 7 \\
(24) \\
20 \cdot 2 \pm 4 \cdot 1 \\
(11) \\
<0.05\end{array}$ & $\begin{array}{l}4 \cdot 6 \pm 2 \cdot 0 \\
(26) \\
4 \cdot 4 \pm 2 \cdot 1 \\
(13) \\
\text { NS }\end{array}$ & $\begin{array}{l}42 \cdot 5 \pm 5 \cdot 3 \\
(21) \\
40 \cdot 3 \pm 3 \cdot 0 \\
(9) \\
\text { NS }\end{array}$ \\
\hline
\end{tabular}

Table 4 Clinical details for the group 2 thalassaemic patients with uncompensated (Cases 1-8) and compensated (Cases 9-13) hypothyroidism

\begin{tabular}{|c|c|c|c|c|c|c|c|c|c|c|}
\hline Case & $\begin{array}{l}\text { Age } \\
\text { (years) }\end{array}$ & $\operatorname{Sex}$ & $\begin{array}{l}\text { Height age } \\
\text { (years) }\end{array}$ & $\begin{array}{l}\text { Bone age } \\
\text { (years) }\end{array}$ & $\begin{array}{l}\text { Stage of } \\
\text { puberty }\end{array}$ & $\begin{array}{l}\text { Clinical } \\
\text { features }\end{array}$ & $\begin{array}{l}\text { Age at first } \\
\text { transfusion } \\
\text { (yea.s) }\end{array}$ & $\begin{array}{l}\text { Units } \\
\text { transfused }\end{array}$ & $\begin{array}{l}\text { Units } \\
\text { transfused } / \mathrm{kg} \dagger\end{array}$ & $\begin{array}{l}\text { Ferritin } \times 10^{3} \\
(\mathrm{ng} / \mathrm{ml})\end{array}$ \\
\hline 1 & $13 \cdot 1$ & $\mathbf{M}$ & $10 \cdot 6$ & - & 1 & S:CF:X & $5 \cdot 0$ & 188 & $5 \cdot 88$ & $5 \cdot 4$ \\
\hline 2 & $13 \cdot 2$ & $\mathbf{M}$ & $10 \cdot 2$ & 一 & 1 & S:CF:CAH:X & 0.3 & 327 & $10 \cdot 22$ & $10 \cdot 0$ \\
\hline 3 & $14 \cdot 3$ & $\mathbf{M}$ & $11 \cdot 0$ & $12 \cdot 8$ & 1 & $\mathbf{S}$ & 0.5 & 245 & $8 \cdot 17$ & $2 \cdot 7$ \\
\hline 4 & $14 \cdot 3$ & $\mathbf{F}$ & $12 \cdot 3$ & - & 4 & CAH & $1 \cdot 3$ & 308 & $7 \cdot 08$ & $4 \cdot 4$ \\
\hline 5 & $15 \cdot 0$ & $\mathbf{F}$ & $10 \cdot 9$ & $10 \cdot 0$ & 1 & $\mathbf{S}$ & $1 \cdot 0$ & - & - & $4 \cdot 0$ \\
\hline 6 & $15 \cdot 3$ & $\mathbf{F}$ & $11 \cdot 5$ & 一 & 1 & S:CF:DM & 0.5 & 343 & $10 \cdot 39$ & $5 \cdot 8$ \\
\hline 7 & $16 \cdot 2$ & $\mathbf{M}$ & $12 \cdot 8$ & $15 \cdot 2$ & 2 & S:CPH & 0.6 & 434 & $10 \cdot 33$ & $2 \cdot 9$ \\
\hline 8 & $23 \cdot 6$ & $\mathbf{F}$ & $13 \cdot 5$ & $14 \cdot \overline{4}$ & 2 & $\mathbf{S}$ & 0.8 & 343 & $7 \cdot 89$ & $4 \cdot 5$ \\
\hline 9 & $11 \cdot 4$ & $\mathbf{M}$ & $10 \cdot 7$ & - & 1 & S:CAH & $1 \cdot 8$ & 273 & $9 \cdot 41$ & $4 \cdot 6$ \\
\hline 10 & $12 \cdot 5$ & $\mathbf{F}$ & $9 \cdot 9$ & $10 \cdot 3$ & 1 & $\mathbf{S}$ & $1 \cdot 0$ & 252 & $7 \cdot 52$ & $5 \cdot 0$ \\
\hline 11 & $14 \cdot 2$ & $F$ & $12 \cdot 7$ & $11 \cdot 7$ & 1 & $\mathbf{S}$ & 0.3 & 278 & $6 \cdot 95$ & $1 \cdot 6$ \\
\hline 12 & $16 \cdot 9$ & $\mathbf{M}$ & $13 \cdot 4$ & $14 \cdot 4$ & 2 & S:C:DM & 0.7 & 292 & $5 \cdot 21$ & $3 \cdot 3$ \\
\hline 13 & $20 \cdot 5$ & $\mathbf{M}$ & $10 \cdot 5$ & - & 1 & S.F:DM:X & 0.7 & - & - & $2 \cdot 3$ \\
\hline
\end{tabular}

$\mathrm{S}=$ splenectomy, $\mathrm{CF}=$ cardiac failure, $\mathrm{DM}=$ diabetes mellitus, $\mathrm{CAH}=$ chronic active hepatitis, $\mathrm{CPH}=\mathrm{chronic}$ persistent hepatitis, $\mathrm{C}=$ cirrhosis $\mathbf{F}=$ fibrosis, $\mathbf{X}$-died.

$\dagger 1$ unit $=300 \mathrm{ml}$ of whole blood. 
in 12 of the 13 hypothyroid and only in 15 of the 27 euthyroid patients from group 2. The mean age of the hypothyroid and euthyroid patients in this group was not statistically different (Table 3 ).

Hepatomegaly was evident in all patients, but all had normal albumin concentration. The serum aspartate and alanine transaminase activities were not raised above the high levels generally seen in thalassaemia major, except in four. Of the group 2 patients, the majority had hepatitis $B$ antibodies and
2 children had hepatitis B antigens. Liver histology from biopsies obtained in 19 patients showed chronic liver disease in 15 patients, 5 of whom were hypothyroid (Table 4) and 10 euthyroid. Two of the 10 euthyroid patients had the low T3 syndrome.

The degree of retardation in height increased with age and was more pronounced in the hypothyroid patients (Fig. 2). The mean bone age was retarded in relation to the mean chronological age by 1.6 and 3.4 years in the euthyroid and hypothyroid patients

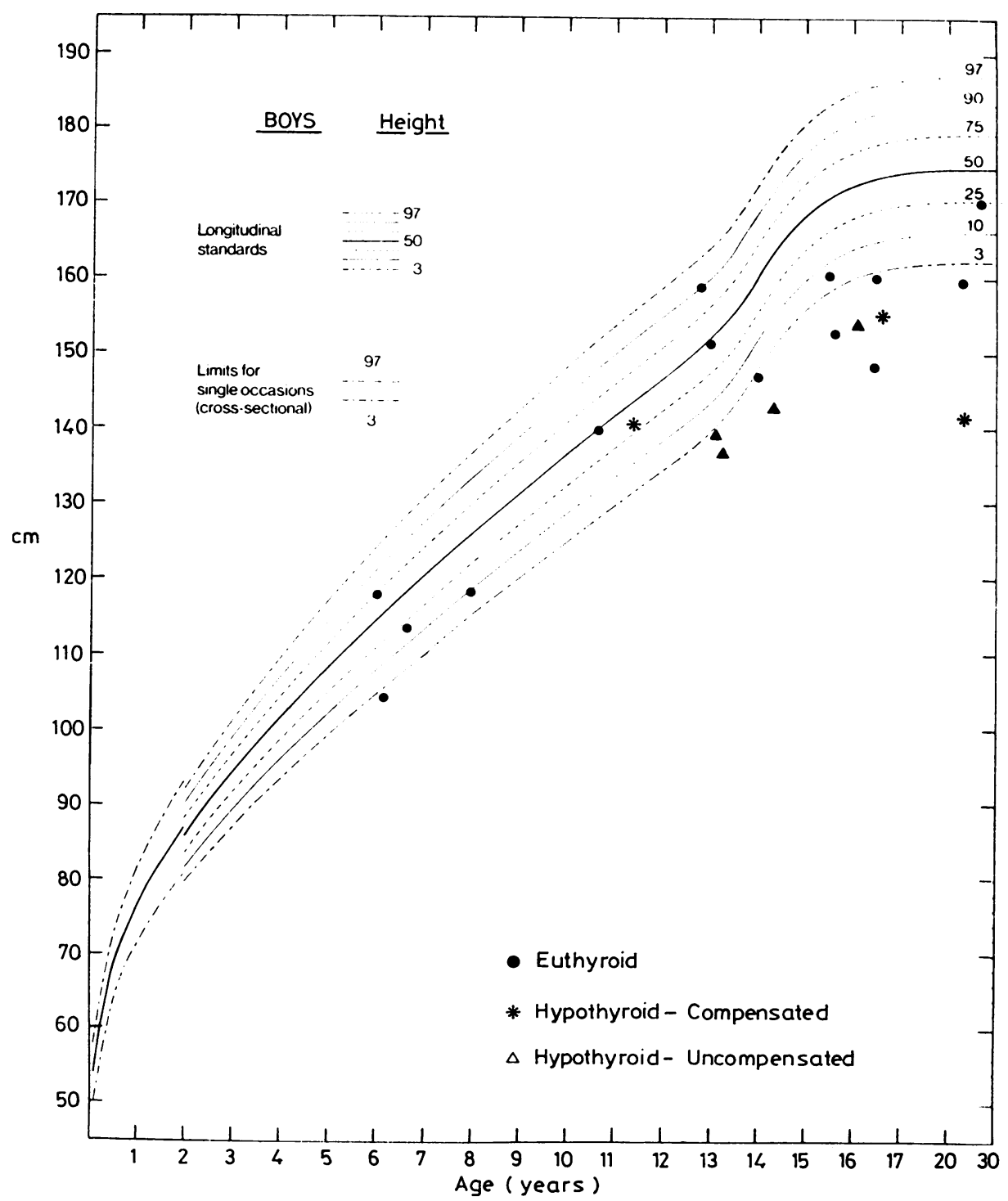

Fig. 2a Heights of boys (group 2) at the time of study plotted on a centile chart. 


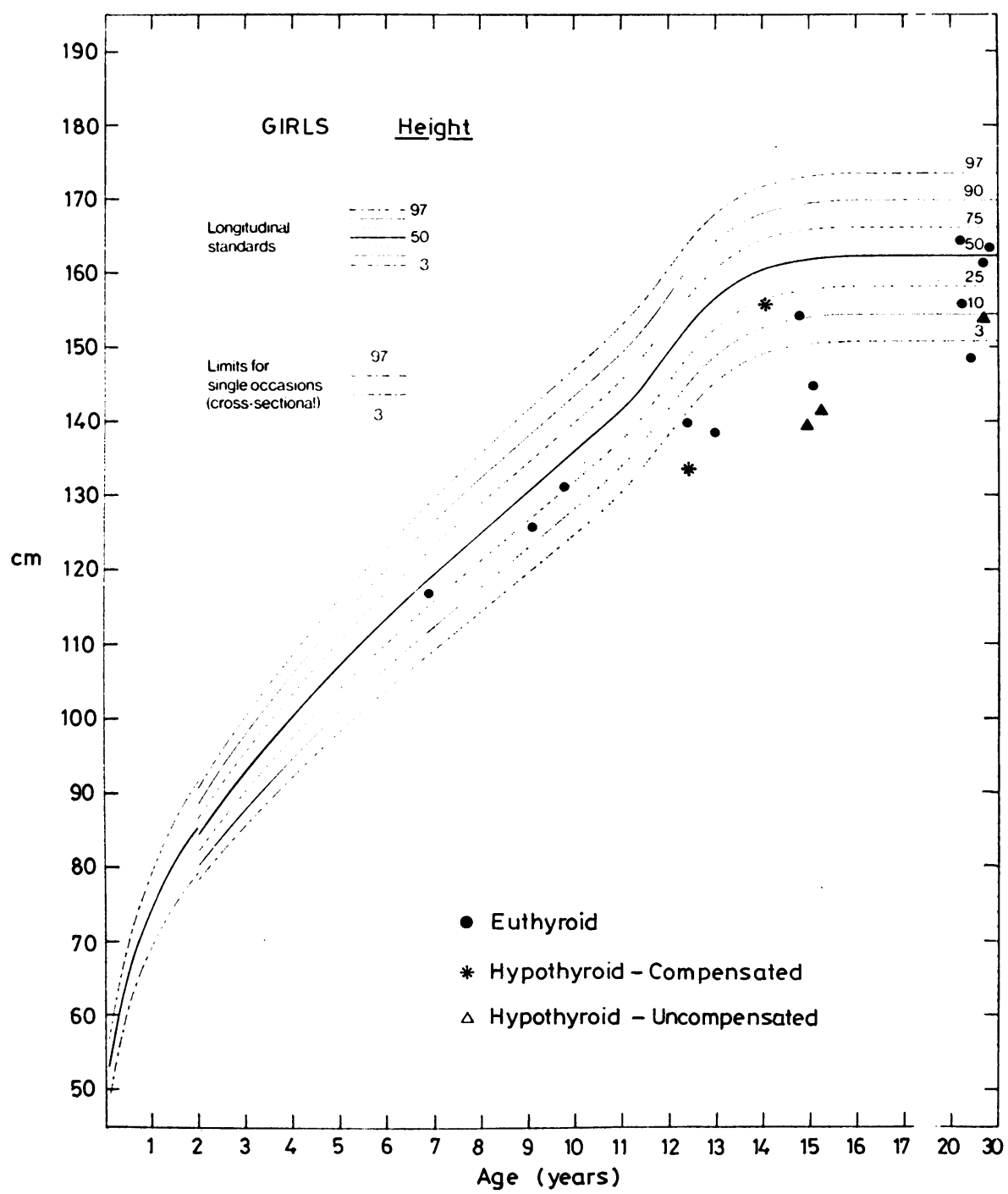

Fig. $2 b$ Heights of girls (group 2) at the time of study plotted on a centile chart.

respectively. In no patient was the bone age retarded with respect to height age by more than 2 years.

The TSH response to TRH stimulation in all patients with a basal TSH greater than $6.5 \mu \mathrm{IU} / \mathrm{ml}$ was more than 2 SDs above the mean for the controls. The TSH response in the patients with the basal TSH level less than $6.5 \mu \mathrm{IU} / \mathrm{ml}$ was within the normal limits in all except four slightly increased responses (Fig. 3). There was a highly significant positive correlation between basal TSH levels and the peak TSH responses $(r=0.931, P<0.001)$. The anti- thyroglobulin titres measured in this group of 25 patients were normal in all.

\section{Discussion}

Primary hypothyroidism was seen in a significant number of apparently euthyroid thalassaemic patients. It was associated with patients of at least 10 years old, a high transfusion iron load, other iron toxicity related complications, and more pronounced growth failure. These characteristics were not reliable guides to the presence of hypothyroidism in 


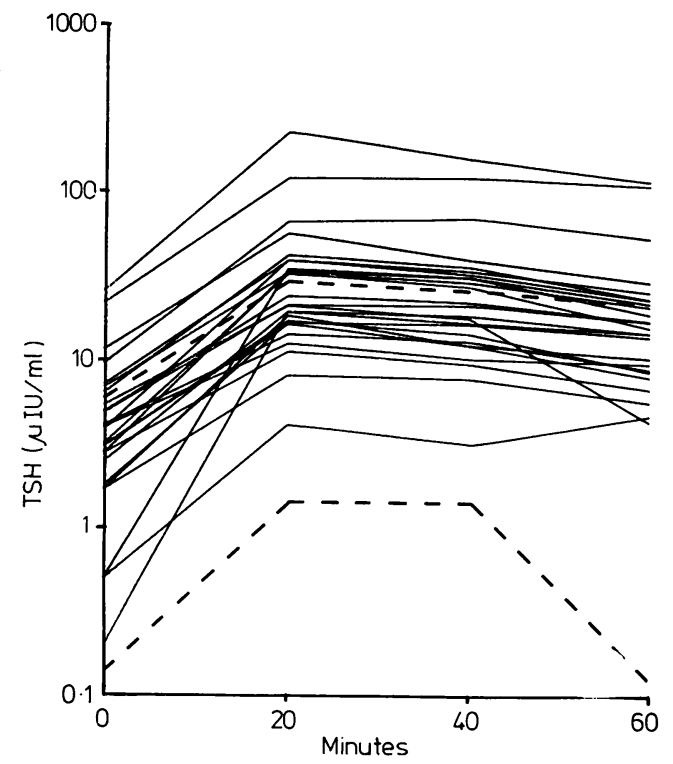

Fig. 3 Serum TSH response (log scale) to intravenous $T R H$ in 25 patients with thalassaemia major. (Dotted lines represent the limits to 2 SDs from the mean of the control subjects $(n=17)$.)

an individual case, and this would explain the variation in conclusions from studies of small and selected patient groups. ${ }^{3589}$ In a study from Sicily ${ }^{10}$ of 45 patients with homozygous thalassaemia normal thyroid function was present in all. A meaningful comparison with our results is not possible because of the failure in that report to give relevant detail (for example, mean age and transfusion data). The patients from southern Italy in our series had an incidence of hypothyroidism similar to that of the Po delta population. The difference in incidence of hypothyroidism noted in the Ferrara $\left(\beta^{\circ}\right.$ thalassaemia) and the non-Ferrara (predominantly $\beta^{+}$thalassaemia) Po delta patient population is probably related to differences in transfusion requirements of the two populations. The blood transfusion load of the Ferrara patients was less (unpublished data) and is consistent with the decreased incidence of hypersplenism and transfusion requirement reported in this particular patient group. ${ }^{2}$ The two Po delta populations were similar in mean age.

An intravenous iron load of at least $0.7 \mathrm{~g} / \mathrm{kg}$ was found in the hypothyroid patients, but some euthyroid patients had this degree of haemosiderosis. Similar concentrations have been reported associated with iron toxicity-related complications and death. The subsequent death in three patients with hypothyroidism (Table 4, Cases 1, 2, and 13) confirms this poor prognosis.

The lack of concordance of the transfusion load and ferritin concentrations with the thyroid function status is in part due to the fact that serum ferritin levels increase linearly with the transfusion load up to 100 units of transfused blood, but thereafter there is no simple relationship. ${ }^{18}$ Misleading ferritin levels also occur with chronic inflammatory liver disease ${ }^{19}$ and vitamin $\mathrm{C}$ deficiency. ${ }^{20}$

Although hypothyroidism was related to a high transfusion load this cannot be equated with a high body iron load since the chelation-related iron excretion was not known.

Immune complexes and autoantibodies including antithyroid antibodies have been found in thalassaemia major patients. ${ }^{1}$ However, antithyroglobulin antibodies measured in 25 patients with a wide spectrum of thyroid function (Fig. 3) were absent and an autoimmune cause for the hypothyroidism is unlikely.

The mean TSH level in the group 1 patients increased progressively with increase in age with the fall in mean TSH level in the 16-30 year age group (Fig. 1) probably occurring because of selection of patients with a milder form of thalassaemia in this older age group, the more severely affected children having died.

The mean age of survival of the patients treated in Ferrara in the last 6 years was 15.7 years (unpublished data). The hypothyroid state was accompanied by a low T4 concentration in only 3 cases (Fig. 1). This reflects the mild nature of the hypothyroidism in the majority as well as a possible increase in T4 due to the high TBG concentration occurring in many patients with chronic inflammatory liver disease. The decreased mean rT3 level of the hypothyroid and euthyroid groups (Table 2) is in accordance with the decrease associated with hypothyroidism ${ }^{21}$ and with some chronic cases associated with the low T3 syndrome.

The low T3 syndrome has been described in adults $^{22}$ and children ${ }^{23}$ with chronic non-thyroidal disease. Decreased T3 and T4 concentrations or decreased T3 and normal T4 with normal basal TSH concentration and normal TSH response to TRH stimulation have been the most common findings. ${ }^{21}$ Decreased peripheral deiodination of T4 to T3 may account for the low T3 level in 9 patients with a normal T4 and TSH concentration. The TSH response to TRH stimulation in 5 of the 9 patients tested was normal, excluding the presence of pituitary hypothyroidism as a possible cause.

The presence of chronic liver disease or the basic disease itself may explain the occurrence of this 
syndrome. The progressive decrease of the T3 level with increasing age of the group 1 patients (Fig. 1) may be related to this phenomenon.

In the presence of chronic disease, non-specific symptoms due to hypothyroidism may not be recognised. Therefore, regular assessment of thyroid function is warranted in patients meeting the highrisk criteria previously mentioned and in patients with compensated hypothyroidism. The increased growth retardation associated with hypothyroidism is unlikely to be due to it since the bone age approximated the height age of the hypothyroid patients as has previously been reported. ${ }^{13}$ The effect of hypothyroidism on already compromised cardiac function (Table 4) in thalassaemia warrants consideration.

Treatment of clinically euthyroid patients with mild hypothyroidism is controversial. The possible decompensating effect of thyroxine treatment on compromised adrenal and pancreatic endocrine function should be considered before treatment. Since the low T3 level associated with non-thyroidal disease is possibly of compensatory value, ${ }^{24}$ replacement therapy cannot be advised.

The strong association of a high transfusion load and decreased thyroid function stresses the need for intensive chelation therapy to be individually monitored to provide negative iron balance with the aim of preventing the iron toxicity-related complications. ${ }^{25}$

We thank Dr J L Penfold for help with preparation of the manuscript; Dr Anna Cavallini and Mrs Angela Angelini for technical assistance; Dr G Candini for statistical analysis; Mrs Nadia Baraldi and Mrs Natalina Capisani for secretarial assistance.

A R S was a research fellow from the Department of Haematology, Adelaide Children's Hospital, South Australia, and was financially supported by the Universita degli studi, Ferrara, Italy. C V was supported by a grant from the C.MR.

\section{References}

1 Zaino E C. Pathophysiology of thalassaemia. Ann NY Acad Sci 1980; 344: 284-304.

2 Modell B. Total management of thalassaemia major. Arch Dis Child 1977; 52: 489-500.

3 Costin G, Kogut M D, Hyman C B, Ortega J A. Endocrine abnormalities in thalassemia major. Am J Dis Child 1979; 133: 497-502.

4 Kletzky O A, Costin G, Marrs R P, Bernstein G, March C M, Mishell D R, Jr. Gonadotropin insufficiency in patients with thalassemia major. $J$ Clin Endocrinol Metab 1979; 48: 901-5.

5 Lassman M N, O'Brien R T, Pearson H A, et al. Endocrine evaluation in thalassemia major. Ann NY Acad Sci 1974; 232: 226-37.

- Ge Sanctis V, Atti G, Lucci M, et al. Endocrine assessment of hypogonadism in patients affected by thalassaemia major. Ric Clin Lab 1980; 10: 663-771.
7 McIntosh N. Endocrinopathy in thalassaemia major. Arch Dis Child 1976; 51: 195-201.

8 Canale V C, Steinherz P, New M, Erlandson M. Endocrine function in thalassemia major. Ann NY Acad Sci 1974; 232: $333-45$.

9 Landau H, Spitz I M, Cividalli G, Rachmilewitz E A. Gonadotrophin, thyrotrophin, and prolactin reserve in beta-thalassaemia. Clin Endocrinol (Oxf) 1978; 9: 163-73.

10 De Luca F, Melluso R, Sobbrio G, Canfora G, Trimarchi F. Thyroid function in thalassaemia major. Arch Dis Child 1980; 55: 389-92.

11 Nienhuis A W, Peterson D T, Henry W. Evaluation of endocrine and cardiac function in patients with iron overload on chelation therapy. In: Zaino $E$, Roberts $\mathrm{R} \mathrm{H}$, eds. Chelation therapy in chronic iron overload. Ciba Medical Horizons Symposium. Miami: Symposia Specialists, 1977: 1-15.

12 Flynn D M, Fairney A, Jackson D, Clayton B E. Hormonal change in thalassaemia major. Arch Dis Child 1976; 51: 828-36.

13 Madeddu G, Dore A, Marongiu A, Langer-Costanzi M. Growth retardation, skeletal maturation, and thyroid function in children with homozygous beta-thalassaemia. Clin Endocrinol $(O x f)$ 1978; 8: 359-65.

14 Burger A, Nicod P, Suter P, Vallotton M B, Vagenakis A, Braverman L. Reduced active thyroid hormone levels in acute illness. Lancet 1976 ; i: 653-5.

15 Bagni B, Malavasi F, Cavalini A R, et al. A 3,3', 5'Triiodothyronine (reverse $\mathrm{T} 3$ ) radioimmunoassay. Ric Clin Lab 1977; 7 : 387-95.

16 Tanner J M, Whitehouse $\mathrm{R} H$, Marshall W A, Healy M J R, Goldstein H. Assessment of skeletal maturity and prediction of adult height (TW2 method). New York: Academic Press, 1975.

17 Corcoran J M, Eastman C J, Carter J N, Lazarus L. Circulating thyroid hormone levels in children. Arch Dis Child 1977; 52: 716-20.

18 Worwood M, Cragg S J, Jacobs A, McLaren C, Ricketts C, Edonomidou J. Binding of serum ferritin to concanavalin A: patients with homozygous $B$ thalassaemia and transfusional iron overload. Br J Haematol 1980; 46: 409-16.

19 De Virgilis S, Sanna G, Cornacchia G, et al. Serum ferritin, liver iron stores, and liver histology in children with thalassaemia. Arch Dis Child 1980; 55:43-5.

20 Cohen A, Cohen I J, Schwartz E. Scurvy and altered iron stores in thalassemia major. $N$ Engl J Med 1981; 304: 158-60.

21 Smallridge R C, Wartofsky L, Desjardins R E, Burman K D. Metabolic clearance and production rates of $3,3^{\prime}, 5^{\prime}$ triiodothyronine in hyperthyroid, euthyroid, and hypothyroid subjects. J Clin Endocrinol Metab 1978; 47: 345-9.

22 Bermudez F, Surks M I, Oppenheimer J H. High incidence of decreased serum triiodothyronine concentration in patients with nonthyroidal disease. J Clin Endocrinol Metab 1975; 41: 27-40.

${ }^{23}$ Ingenbleek $\mathrm{Y}$, Beckers $\mathrm{C}$. Triiodothyronine and thyroidstimulating hormone in protein-calorie malnutrition in infants. Lancet 1975 ; ii: $845-7$.

24 Cavalieri R R, Rapoport B. Impaired peripheral conversion of thyroxine to triiodothyronine. Ann Rev Med 1977; 28: 57-65.

25 Pippard M J, Callender S T, Letsky E A, Weatherall D J. Prevention of iron loading in transfusion-dependent thalassaemia. Lancet 1978; i: 1178-89.

Correspondence to Professor C Vullo, Arcispedale S Anna, Ferrara, Italy 44100.

Received 16 August 1982 